\title{
Customer Relationship Management: Related Theories, Challenges and Application in Banking Sector
}

\author{
Babin Pokharel \\ CEO, VS Niketan College, VS Niketan Higher Secondary School \\ Email: info@vsniketan.edu.np
}

\section{What is CRM}

Customer relationship Management (CRM) appears to be a simple and straightforward concept, but there are many different definitions and implementations of CRM. At present, a number of different conceptual understandings are associated with the term "Customer Relationship Management (CRM). There understanding range from IT driven programs designed to optimize customer contact to comprehensive approaches for the establishment and design of long-term relationships. The effort to establish a meaningful relationship with the customer is characteristic of this last understanding (Barnes 2003).

CRM is a holistic process of acquiring, retaining and growing customers. It includes all in-line and off-line relationship management. (Strauss et al. 2003). As gray and Byun (2001) expound; CRM is an abbreviation for customer relationship management, not customer relationship marketing. Management is a broader concept than marketing because it covers strategic management, human resources management, marketing management, service management, knowledge management, sales management and research management and development management. Thus CRM requires organizational and business level approaches, which are customer centric, to doing business rather than a simple marketing strategy.

The banking industry is facing an ever-increasing level of competition around the world as the dynamics of the business change. Technology, commoditization, deregulation and globalization forever changed the face of banking (Joyner 2002). Banks have understood the need to capitalize on the new technologies to gain advantage in the competition by exploiting their customer base, brand value and costly infrastructure investments in order to increase profits, as there's a direct link between the customer satisfaction and the profitability. CRM is the strategy which enables the banks to analyze the customer profiles, to detect their needs and potential profitability areas and establish the necessary actions the achieve customer satisfaction, competitive advantage and thus the profitability. From the customer's points of view, the competition brings them various choices and increases their bargaining power. Today, customers are looking for various benefits from a bank; better service, lower transaction fees, higher interest rates, a sign of prestige, new products access from different channel and etc. this scheme forces the banks to look for new ways a satisfy customers before any other bank or financial institution does. 


\section{Critical Success Factor of CRM}

CRM is a holistic approach, which needs alignment of different aspects of a business. Management and leadership, change management, human resources and using right technologies are the critical success factors of CRM.

\section{Management and leadership}

Leaders/Mangers in a bank should have an important role by sharing CRM team's vision with management. The leaders' role has to be facilitator for implementing CRM. Effective Leadership skills result in CRM success. Innovative mangers works with his team, makes decisions by consulting his team, whilst still maintaining control of the group as well as appreciate all the feedbacks in the organization related with CRM implementation and strategies and tries to integrate people into it. Because CRM is the backbone of communication, manager communication and coaching skills is the important in CRM implementation any banks.

\section{Change Management}

"CRM is an evaluation. Change is inevitable." When new IT systems, software, etc. are deployed, the way people doing their jobs would also change, so cultural change adaptation is crucial. It can be also called as Multi Pronged Change Strategy. Instead of rushing, CRM team can prefer a gradual change. Workshops and brainstorming meetings with sales, marketing, and customer service staff and shared their CRM strategies can be conducted. Banks do train employees and first of all, they tried to change employees' mindset from operation centric ones to customer centric ones. Change management is crucial to promote user adaptation. Major focus is based on training to achieve adaptation.

\section{Information Technology (IT)}

Nowadays many banks began to deploy new technologies according to their needs. With advanced technologies, it gets the advantage of doing tasks faster and more accurately. There are various software for CRM like Siebel systems for operational CRM; Teradata for data warehouse; Unica's Affinium for campaign management; SAS for data modeling activities. Banks also develop a task manager program that helps sales representatives to see 360 -degree of customer view.

\section{Human Resources}

CRM is the backbone for communication. For a successful CRM implementation, human resources management of a company is very important. Integrating employees into strategies and training them is very important to adapt them to change. Employees are the interface of the company, so they will highly affect the bank's image.

\section{CRM for Competitive Advantage}

Competition is at the core of the success or failure of a bank as well as all the firms. According to porter (1985), competitive strategy is the search for a favorable competitive position in an industry, the fundamental arena in which competition occurs. Competitive strategy aims to establish a profitable and sustainable position against the forces that determine industry competition. 
There are various strategies that can be adopted which will procure a bank competitive advantage in an industry. In this study, Poter's "Generic Strategy Framework" and Treacy \& Wieserma's "Value Disciplines Model" are discussed and adapted to banking industry which will be helpful to understand and evaluate the positioning strategies of banks in terms of their CRM strategic and implementations. Strengths and weaknesses of these strategies and their applicability to banking industry are argued; comparisons are conducted accordingly.

\section{Generic Strategic Framework}

"Competitive advantage grows fundamentally out the value a firm is able to create for its buyers that exceeds the firm's cost of creating it. Value is what customers willing to pay and superior value stems from offering lower prices than competitors for equivalent benefits of providing unique benefits that more than offset a higher price." (Porter 1985, p.3)

The theory consists of three main strategies (cost leadership, differentiation and focus) which are shown in the figure 2.1 while cost leadership and differentiation strategies address a whole industry, focus strategies address specific or small clusters of customers within an industry.

\section{Competitive Advantage}

ปั๊

Broad Target
Narrow Target

\begin{tabular}{|l|l|}
\hline 1. Cost leadership & 2. Differentiation \\
\hline 3a. Cost Focus & 3b. Differentiation Focus \\
\hline
\end{tabular}

Figure 1: Three Generic Strategies of the Generic Strategies Framework

(Source: Porter, 1985, Competitive Advantage, p. 12)

\section{Cost Leadership}

The strategy requires a firm (bank) to serve at the lowest cost in the industry. Economies of scale, unique technology that is not available to other firms, using cost effective channels are some of the ways for being able to use the strategy. The strategic logic of cost leadership strategy requires a firm to be cost leader, not one of the several firms vying this position.

For banking sector, a broad target cost leadership strategy itself is not a good strategy as it decreases the profit margins extensively which will soon be followed by other banks. That's why there is no significant difference in general interest rates, loan rates, transaction fees of bank in a stable economy and banking sector. 


\section{Differentiation}

The aim of the strategy is to be unique in the industry and this uniqueness must be valuable for customers. The uniqueness can be one or a set of dimensions. Areas of differentiation can be: product service, marketing, sales, image, delivery and etc.

In banking sector, differentiation can be crafted by a single or a set of these dimensions. While brand differentiation and product differentiation would be applicable for broad targeting service, marketing and delivery differentiation strategies would be suitable for narrow scope targeting. A broad target service differentiation is not for banks they are looking for profitability. That is why today many banks use customer segmentation to service its customers rather than given the same service to all customers.

\section{Focus Strategy}

The focus strategy involves concentration on particular buyer groups, geographic areas or product/market segments. By selecting a particular segment group or group of segments, company attempts to tailor its strategy to service the needs of its segment better than the competitors. A focus strategy may emphasize differentiation or cost advantage (Payen). Events based marketing is an example of focus differentiation strategy (marketing differentiation), which matches customer transactions to tailored marketing and sales pitches Priority banking is another example of focus differentiation strategy (service differentiation), which aims to give better service to more profitable customers of a bank. Today customers look for individualize service from their banks and banks highly use focus differentiation strategies to satisfy customers. Banks use "cost focus strategy" mostly for profitable customers in order to retain them by increasing their switching cost.

It can be synthesize that, for banking sector, board target differentiation strategies are likely to attract the potential customer, while narrow target differentiation strategies (focus strategy) are likely to retain bank's existing profitable customers and allocate the bank's resources more effectively. For example, brand, image of the bank is an important why for bank to differentiate themselves from all the other banks and attract potential customers. Launching innovate products is another why of attracting potential customers.

Michael Porter (Porter 2006, cited in Streeter 2006) states his thoughts, about competition and banks, in a recent banking conference. Porter thinks that banking sector is entering an era of strategic positioning. To succeed in the new era, companies have to deliver something unique, but most banks do what others do, what he calls, to competition. He stated that "The worst thing you can do is compete with your rival on the same things. If you do, the competition almost always becomes a destructive arms race. Strategy, is striving to be unique, which required choices."

As it can be understood, porter insists the successful firms can only compete with one generic strategy, in isolation of other generic strategies. For many researchers this viewpoint is not accurate. What should be pointed out is the successful firms 
tend to compete with multiple strategies. Contingent strategies are important for their survival. (Hall 1983; Ham brick 1983; Wright, 1986, cited in Wright et al 1988)

The other critical view for porter's monolithic strategy comes from Wright (1986 cited in Wright et al.), he expounds that in a fragmented industry like banking, where there the many players in different sizes, it is difficult to be successful with adapting one generic strategy.

In banking industry, a sustainable competitive advantage can be gained with a blend of different strategies, but a powerful focus differentiation strategy in service cannot be neglected. Products and price can be easily copied. Service is more difficult to imitate than a product because service requires customer input and involvement (Payen 2006).

Today, building a competitive advantage is based on how well a bank serves its customer CRM is differentiation strategy that banks can use to acquire, grow and retain profitable customer relationships, with the goal of creating a sustainable competitive advantage.

In the following part, another important competitive advantage strategy framework will be discussed and comparisons will be done with porters' Generic Strategies framework

\section{Value Discipline Model}

Porter's "Generic Strategies Framework" alone is not enough to understand the positioning strategies of banks in terms of CRM. Porter's focus on industry structure is a powerful means of analyzing competitive advantage in itself, but it has been criticized for being too static in an increasingly fast changing world. For a deeper understanding, Michael Treacy and Fred Wieserma's "Value Disciplines Model" has been examined. This model is another important strategic framework for market positioning which has the following 3 positioning strategies:

- Operational excellence

- Product leadership

- Customer intimacy

CRM can be strategically embedded particularly in two of the three value disciplines (1) Operational Excellence, and (2) Customer Intimacy. With customer intimacy, Wieserma (1998) shows how companies can profit from establishing closer, more co-operative customer relationships. With operational excellence, firms aim to have economical, efficient processes whose resulting delivered values to customers are low prices and service convenience. (Wieserma \& Treacy 1996).

Firms applying customer intimacy focus on knowing the customer and building close relationships with these customers. CRM is often solely related to the customer intimacy value discipline. If CRM is embedded in a customer intimacy strategy, then CRM will be relationship-oriented. Firms embedding CRM in an operational excellence strategy focus on cost- reductions and raising the quality of the 
customer interaction process through process improvements (Verhoef and Langerak 2002).

\section{Challenges of Implementing CRM}

The challenges faced by many of the banks whilst implementing CRM can be summarized as the followings:

- Getting management sponsorship

- Quality of customer data

- $\quad$ Alignment issue (Alignment of people and processes)

- Lack of skilled people

- Determining the right time for customer needs

- Using customer data more intelligently

- Incorporating customer data and customer preferences to the customer data base

- Using right technologies

- Real time data cross all customer channels

- Having 360- degree view of customers (Single view of customers)

The retail banking market is fiercely competitive and saturated (Pili 2006). The competition is forcing banks to find new ways of satisfying customers and quick adaptation to changes. The competition among the banks itself is also very major domestic players on the arena. Banks are aware of this fact and exploit new trends to continue their existence in the market. CRM is one of these trends that are highly adopted by many banks.

The satisfaction level of customers who agree that they are treated as a valued customer is the measuring part for CRM's success in the bank. This could be attributed to the distinctive communication capabilities, which target to establish an emotional link with the customer. This is highly related with organizational learning philosophy and adaptive culture of the banks.

\section{Application of CRM in Banking Sector}

Based on the discussions made above, appropriate and effective application strategies of CRM are given to improve bank's competitive position in the market.

\section{Changing Mindsets}

\section{Customer Centric, Adaptive, Innovative Culture}

Any bank's long heritage brings rigid and conservation mindsets together which makes the change adaptation difficult, which is essential for CRM as mentioned in the "Critical Success Factors of CRM" part. Although this rigidity seems to be decreasing, a mindset change is needed for the bank.

The rigidity of management and the conservative hierarchical organization structures decrease the speed of CRM implementations and operation in banks. Banks can use any other good bank which is implementing CRM as benchmarks, which have more flexible and innovative cultures and where organizational structure is flatter. The charge of mindsets must start from the management level and continue to the all the level of the organization with the support of 
management. At this point a paradigm shift is needed which can be summarized as follows:

- A customer centric and relationship-oriented culture must be adopted instead of operation centric and sales oriented culture.

- Management's attitude to employee must be proactive instead of being reactive; instead of employee compliance, continuous improvement must be supported.

- Training culture must be improved to organization learning philosophy where self-learning is supported.

- Employee must be empowered in order to carry on their responsibilities faster and efficiently.

- Teamwork and coaching must be developed, instead of individuation.

- Measurement basis must be objective, fair and transparent. Employee must be motivated by rewards and supportive attitude of their managers.

Leaders play an important role in this change process. So that banks can invest in experienced professionals with leadership skill, which can influence the organization to encourage and convince for change. Banks also must consider employee career development and leadership training. They can overcome the problem of absence of skilled people regarding with CRM by training employee with the help of leadership coaching.

Mission statement of bank must be revised and statements that are stressing the customer focused, innovative culture must be put in place. This focus must be supported with in-house training and the message should be clearly passed down to each level in the organization to ensure solid commitments.

\section{Organizational Learning Philosophy}

Organizational learning is more than providing training sessions to employees when it is needed; it is a philosophy. Banks must introduce organizational learning philosophy to nurture new and expansive patterns of thinking where innovative thinking is supported. Organizational learning philosophy consists of a fast adaptive culture, which is an important core competence for today's banking industry. Leadership coaching can help in adaptation process. Also e-leanings about technical and non-technical issues can be provided via intranet connection of Banks. Banks can exploit organizational learning philosophy while implementing its CRM strategies employees and customers are the end user of CRM strategies and implementations, so that it can capitalize on their feedbacks, expectations, satisfaction and dissatisfaction points to improve its strategies and implementations. Banks can conduct regular discussion sessions with employee and customers. New products, services of the bank can be shared and customers' offering for better products and services than its competitor can be learned customers' further expectations can be sought which would be crucial for further product and service design. This help bank to understand needs of customer's factor competitors, which result with innovative product and services. This is also an impotent way to explorer and rectifies problems face by users quickly, which paves the way for operational excellence and customer intimacy. All these mindset changes will help banks to 
overcome the alignment problems, alignment of people and processes, which are obstacle in the CRM success.

\section{Building Brand Image}

If banks seem to have an introverted culture; it must adopt a more extroverted culture to promote its brand. This needs a change in mindsets from management level to employees' level. By using CRM, it can build strong relationships with customers. The successful service excellence and customer intimacy strategies can result with good word of mouth which is the most effective way of advertisement. Employees can play a critical role in building a strong brand. Banks must equip its employee with necessary mindsets and skill so that they will play as an ambassador role in promoting brand identity. Banks have some CRM capabilities that the order banks don't have so it must promote its superior capabilities better a build a strong brand. They can use more advertisements on TV, newspapers, and magazines, Internet etc. By using CRM capabilities, banks can find out customers' needs and expectations faster than rivals and accordingly can launch innovative products and services. Innovative products attract new customers and promote brand as a pioneer in the market.

\section{Re-Integration of Operational Analytical and Collaborative CRM}

Although many banks have very high analytical CRM capabilities, they have deficiencies in operational and collaborative CRM. So banks can overcome the challenge of insufficient quality of customer data by using an integrated CRM system and interacted channel management. To enhance its operational CRM, bank should adopt the mindset changes to equip its sales force with necessary mindset and skill to integrate them to new processes. To improve customer service automation and collaborative CRM capabilities, banks should use an "Interacted channel management" Online banking is very crucial for today' bank's customers. So banks should direct its customers of online channels, which reduce cost and increase speed of transactions for both parties. It will also ease the tracking of customer information. Various systems such as web-chat and call back services to its communication channels add value to CRM. Also, banks must develop its telephone banking. And all channels must be integrated with each other.

\section{Effective Use of ATMs}

ATMs are very important for the bank choice of people. Banks have to capitalize on their ATMs better by expanding their branch network, locating ATMs into strategic points where they can each more people. With new ATMs in existence, customers can update their information, which is a strategic way to improve customer data. As it is a new service. Introduction brochures must be placed near ATMs, explaining their use and also a demo may be put into web site, which shows which transactions can be done by ATMs and may show all the ATM transactions step by step. So that customer feels more confident when they first use it. Because people are afraid to their bankcards might get caught in the ATMs because of any misuse.

\section{Increasing Switching Cost}

In order to retain customers and increase existing customers' share of wallet, Banks must develop strategies that will increase switching costs. It can increase switching 
cost with excellent service, customer intimacy and focus differentiation strategies. By building emotional links with customers and making they feel as a valued customer. Other tactics are giving more reward points and using competitive pricing and promotion strategies. Promotion may be important for credit card holders.

\section{Focus on Private and Premier (Priority) Banking}

Many banks already practice private banking and priority banking but in order to incorporate CRM to the highest, it should be strong player in private market. One of the main aim and ultimate goal of CRM is to retain and acquire must profitable customers, which affect overall the profitability of bank. To attract more private banking customers, banks must offer more individualize and attractive products and services to these customers. And its advertisement and packing must be done well. On the other side, like what some other banks do, banks can use referral programs. In return shopping vouchers can be offered to customer who can introduce a private banking customer successfully. To retain private banking customers, more waiver and discounts must be used. To increase their profitability, their saving can be attracted by educating and advising them about the financial markets and financial products. Banks should also pursue the strategy to grow profitability of customer who is not highly profitable at the moment but have the potential to become.

Lastly as universally understood customer satisfaction is very important for the aim of CRM, effective and efficient customer satisfaction management strategy should be enabled to analyze the customer profiles, to detect their needs and potential profitability areas and establish the necessary actions to achieve customer satisfaction, competitive advantage and thus the profitability. To sum up, any banks can exploit CRM in order to gain competitive advantage over its rivals and increase their customer base for having bigger slice of pie.

\section{REFERENCES}

Aranata, M.(2006), "CRM Resurgence in Asia: Which Banks Lead the Change?", Finacial Insights.

Argyris, C \& Schon, D.( 1978), "organizational Learning: A theory of sction perspective", Reading, Mass: Addison Wesly.

Barnes cited in stauss, B \& Seidel, W.(2004),"Complaint Mangement:the heart of CRM", 1st Edition, Thomson, America.

De Felice, A \& Britt ,P.(2005) "Banking on Big Green", Medford: Customer Relationship Management"Vol 9:11, p.34

Forbes, S.(2004)," Creating Profitable Customer Experiences", American Banker, Vol.169, Issue 221, p 22rd-22rd,1p

Hershey, L.(2001),"Why CRM Implementation fail. What Part Don't you Understand."

Imhoff ,C, Geiger \& Lofits,L.(2001). "Building the customer-centric Enterprise", February 2001, Jhon Wiley \& Sons.

Jackson,D.(2002), "CRM in financial services", A service excellence white paper , p.10 retrieved April 14, 2011 from www.serviceexcellenceawards.com

Joyner, E .(2002),"Customer Relationship Management in Banking ", SAS White paper, North Carolina offices. 
Meltzer, M.,"CRM means change", The wise Marketer. Retrieved April 14, 2011 from http://www.thewisemarketer.com

Mochal, T.(2006) ,"10 points to guide you towards CRM success". Retrieved April 15, 2011 from http://news.zdnet.co.uk/itmangement.

Payne, A (2006),"Handbook of CRM: Achieving excellence in customer management", Butterworth Heinenmann, Great Britain.

Peter, M. Senge ," The fifth Discipline: The art \& practice of the learning organization", Currency Doubleday, New York.

Porter, M E.(1985),"competitive Advantage :creating and sustaining superior performance", 2004 Edition, Free Press , Newyork.

Rigby. D \& Ledingham, D, (2004)," CRM done right", Harvard Business Review, November 2004, p.11

Treacy, M \& Wiersema, F. (1996), "The discipline of Market Leaders", London, HarperCollins Business. 